\title{
How the Peruvian Agrarian Reform Affected the Human Rights of Peasants
}

Cómo la Reforma Agraria peruana afectó los derechos humanos de los campesinos

Allen ZegarRa ACEVEdo ${ }^{1}$

\begin{abstract}
The colonial land tenure in Perú affected the previously existing communal system of land tenure in several ways. This new system of ownership and forced agricultural labor changed over time. However, the semi-slave condition of the indigenous peasants of Perú remained the same until the late 1960s. The Agrarian Reform started in 1969 and had an unprecedented impact on the living conditions of peasants. This article claims that the life of peasants in latifundia before the Reform had been extremely precarious due to an inexistent set of fundamental human rights. Based on an analysis of articles, interviews, testimonies, the Political Constitution of Perú of 1933, and case studies this research explores the socio-economic and political circumstances under which the Peruvian Agrarian Reform was started. Moreover, it provides instances of the positive repercussions that the Agrarian Reform has had in Perú in the realm of human rights practice.
\end{abstract}

Keywords: Human Rights, Agrarian Reform, Land Tenure, Peasants, Perú

\footnotetext{
1 Ph.D. candidate in the Department of Spanish and Portuguese Studies at the University of Florida
} 
Resumen: La tenencia de la tierra establecida durante la Colonia afectó en varias formas al sistema de posesión de tierra comunal que existía antes en el Perú. El nuevo sistema de propiedad y trabajo agrícola forzado cambió con el paso del tiempo. Sin embargo, la condición de semiesclavitud del campesino peruano permaneció igual hasta finales de la década de los años sesenta. Este trabajo sostiene que la vida de los campesinos en los latifundios antes de la Reforma Agraria había sido extremada precaria debido a la inexistencia del más mínimo conjunto de derechos humanos. Con base en un análisis de artículos, entrevistas, testimonios, la Constitución Política del Perú de 1933 y estudios de casos, esta investigación explora las circunstancias socioeconómicas y políticas bajo las cuales inició la Reforma Agraria en el Perú. Además, brinda ejemplos del impacto positivo que ha tenido la Reforma en la práctica de los derechos humanos.

Palabras claves: Derechos humanos, Reforma agraria, Tenencia de la tierra, Campesinos, Perú

Recibido: 15.10.2021 Aceptado: 27.12.2021

\section{Summary}

1. Land Tenure and its Implications before the Agrarian Reform

2. The Agrarian Reform and the Human Rights of Peasants

3. The Effects of the Reform on the Human Rights of Peasants

4. The Reform: Present and Future

5. Conclusions 


\section{Land Tenure and its Implications before the Agrarian Reform}

Once the Spaniards had conquered Perú, those who had contributed to the Spanish cause were compensated with plots of land. The land granted to a man was assigned along with the people who inhabited it. The person who received this grant was called encomendero and the system whereby the natives' labor was exploited was called encomienda. Historian Charles Gibson states that the encomienda turned out to be a highly oppressive system. Encomenderos had the natives work long hours and punished them both physically and morally if they dared to disobey orders. Punishments ranged from thrashing to food deprivation. Gibson suggests that the encomienda system was indeed a disguised slavery system. He states that:

Encomienda Indians were overworked, abused, bought, and sold, and otherwise treated in ways that did not distinguish them from non-encomienda Indians. And, even according to law, those who escaped might be recaptured and condemned to outright slavery, as punishment for neglecting their obligation to 'voluntary' work. (1966)

It is apparent that encomienda was just a euphemism for slavery. Although Charles V introduced The New Laws, which were promoted by Jesuits, among them Las Casas, to put an end to the abuses, humiliations against natives remained. The encomienda was often hereditary (Gibson 1966), and its inhumane features were also passed down from generation to generation.

More than a century after Perú gained its independence, the encomiendas became latifundia. The legal system of land tenure changed, but what remained the same was the dispossession of the natives and the abuses committed against them. Along with land deprivation came a semi-feudal system of mastery personified by the 
latifundia owner ${ }^{2}$. It is in that context that the figure of the 'gamonal' (cacique) appeared. The former encomendero took on a freer role, as he was no longer submitted to the Crown, and exerted great political, economic, and social power in his domain. According to anthropologist Jesús Contreras, the first time that the term 'gamonal' was used dates to 1863. It was described by a columnist from Revista Americana as follows:

[...] they call gamonal (so as not to say foreman or cacique) a rich man living in a small place, who owns the most valuable lands, sort of feudal lord of a parish, who influences and rules freely in a district, handles his lessees as if they were lambs, and exerts his will as if he were the caricature of saint Peter, and stands out unrivaled like a rooster amidst hens. The gamonal is consequently the satrap of a parish. (1981)

It comes as no surprise that the description includes the term "feudal lord" to characterize a 'gamonal'. Gamonales were all over rural Perú, and regardless of some distinct features between them and encomenderos, they mainly performed the same role: owners of land and masters of servants.

It is evident that gamonalismo was a tyrannical system. It fed off arbitrariness and illegitimacy. Contreras analyzes the ramifications of gamonalismo in Chinchero, a district in Cusco. Although this is only one of the many gamonalismo cases that date back to the 20th century, it portrays the essential characteristics of this system of land tenure and its political, economic, and social implications. Contreras

\footnotetext{
2 Authors usually differentiate between landowners and gamonales based on their backgrounds and the origins of their land tenure. However, when it comes to the excesses they committed against peasants prior to the Agrarian Reform, the terms become indistinguishable. Manuel González Prada makes this evident in "Horas de lucha" (Hours of fight). A fragment of his book reads: "If on the coast there is a glimpse of guarantee under an imitation of the Republic, in the interior the violation of all rights is palpable, under a true feudal regime. There are no codes in force, nor do courts of just prevail, because landowners and gamonales settle every issue, assuming the roles of judges and executors of sentences. The political authorities, far from supporting the weak and the poor, almost always help the rich and the strong".
} 
claims that gamonales usually increased their land possessions by unfair and fraudulent means. The natives that owned small plots of land ${ }^{3}$ sooner than later had to part with the source that rendered them a bit of freedom and became links of the long chain of servitude. Contreras argues that peasants were doomed to live in oppression while gamonalismo existed. He asserts that "[...] peasants could not complain about the abuses that they were subjected to by gamonales since courts of law never ruled in their favor, given the political, social, and economic ties that different ranking officers or authorities themselves held with them [gamonales]" (1981). However, taking peasants' land was only one of the different ways in which ordinary people's rights were disrespected. Gamonales were, to a large extent, a new version of feudal lords, and as such employed not only brute force but social influence to make the most of the peasants who lived in their domains or in the vicinity. Contreras suggests that gamonales became godparents to scores of peasants. Their godchildren's parents became in turn their compadres. In the Andean world, being a godparent is synonymous with being a parent. The alleged respect owed to padrinos and compadres allowed for what some anthropologists have called 'vertical exploitation'. Contreras states that the appropriation of unpaid labor was carried out in different ways. The following is a statement cited by him from a member of a community called Ayllopongo, in Chinchero (Cusco), who seems to be aware of how a gamonal uses his condition as padrino and compadre to exploit peasants:

In D. Fidel's case, since he has deceived the people, and as he has hundreds and hundreds of godchildren and compadres, they work as if they were hired on a farm. When he needs them to work, the people come. That is how he thrives, since he

\footnotetext{
${ }^{3}$ The Spanish Crown had allotted small plots of land to the natives as individuals and to the different communities made up by the natives for their own subsistence. This allotment occurred mainly between 1595 and 1617. Donato Amado Gonzales concludes that the visits organized by the Crown during that period of time ended up in a large increase of the land tenure in favor of the Spaniards to the detriment of the land tenure of the natives.
} 
does not pay at all. He just gives them one or two soles for their chicha drinks. That is how he thrives. (Contreras 1981)

Contreras claims that if simple persuasion did not yield positive results, gamonales turned to the police (Guardia Civil) so that they could exert repression on 'rebellious' peasants. In effect, the police were at the disposal of gamonales who, according to Contreras, were the de facto local authorities.

José Carlos Mariátegui denounced the exploitation of the Indians in Siete ensayos de interpretación de la realidad peruana in 1928. He stated:

Gamonalismo inevitably invalidates any law or ordinance that protects the indigenous. The landlord, the landowner, is a feudal lord. Against his authority, paid by the milieu and custom, the written law is impotent. Unpaid labor is forbidden by law; however, unpaid labor and, even, forced labor remain alive in latifundia. (2012)

Unpaid and forced labor characterized the encomienda that came to an end in the 18th century. Nevertheless, the inhumane features of this medieval socio-economic institution did not disappear. On the contrary, the abuses committed by gamonales against peasants were consented with the complicit and often unscrupulous silence of state authorities.

Due to an absolute disregard for the human rights of Indians, the condition of peasants in Perú, prior to the Agrarian Reform, was on a par with one of servitude or disguised slavery. A CBS report shows the inhumane situation of peasants living in the highlands of Perú. Reporter Charles Kuralt contrasted the past of a great civilization like that of the Incas with the humiliation that their descendants were experiencing towards the end of the 20th century. The report talks about Vicos, a former hacienda located 250 miles from Lima, which the reporter describes as being "just 10 years out of the 16th century". What is described next is key to the main argument of this essay. While showing images of Indians marching and bowing in front of an 
elegantly dressed man, the reporter says: "Not far from this hacienda are many others where the Indians with the same heritage [Inca] are servants willing to bow down their heads in submission to the man who owns or rents them. If they are unwilling to submit, they may starve slowly [...]" (CBS, 2017, 0:09-1:04). It is worth mentioning that this report broadcast by the CBS is entitled "Perú before the Agrarian Reform" to establish the context in which the events described occurred. The fact that the reporter says that the landowner owns or rents these peasants reveals the condition of slavery that pertained to the descendants of the Incas. ${ }^{4}$ Since they were subjected to trade, they were reified; thus, deprived of human rights. As aforementioned, gamonales not only took over vast stretches of land, but the lives of Indians who dwelled in or close to their domains.

Their right to life was subject to the will of the landowner. Peasants could be traded off. As a result, they were stripped of any rights that a free person is expected to have, such as freedom of expression and opinion, the right to paid labor, and education, all of which were acknowledged in the standing Political Constitution of Perú of 1933. In brief, dignity was a privilege exclusive of the dominant class in the rural world. To that point, in 1965, Roberto Mac-Lean wrote:

The Indian does it all: his effort and sacrifice nourish the land of gamonales. And the compensation for his work with the usufruct of the land means, almost always, the most rigid form of servitude, anachronic survival, incompatible with the respect for the dignity of a human being. Many seem to forget that the Indian is one. That is why latifundium becomes the insurmountable obstacle for the incorporation of the indigenous peasant-several million of current pariahs-into

\footnotetext{
${ }^{4}$ The socioeconomic condition of the Chinese immigrants (coolies) and that of the Afro descendants was deplorable as denounced by Manuel González Prada in his essay "Nuestros indios" (Our Indians) at the beginning of the $20^{\text {th }}$ century. Both Chinese immigrants and Afro descendants were employed mainly on coastal farms. However, renting peasants was a local practice among landowners in the highlands of Perú.
} 
the exchange economy, the culture, and life on a national level. (1965)

Mac-Lean criticizes the exclusion and disgraceful condition of millions of Peruvian peasants. He was one of many who claimed that peasants deserved to be treated with dignity. It is under such inhumane circumstances that de facto president Juan Velasco Alvarado started the Peruvian Agrarian Reform in 1969.

\section{The Agrarian Reform and the Human Rights of Peasants}

This research paper claims that before the Agrarian Reform, Peruvian peasants were not entitled even to the most fundamental human rights; consequently, they led very precarious lives. Although there is still controversy around the economic consequences of the Agrarian Reform, there is no doubt that it introduced a new praxis of human rights in the Peruvian rural sectors. While Velasco's regime was a typical dictatorship in terms of individual liberties, the core of the Reform aimed at restoring peasants' dignity. By allowing them to possess land and grow their own crops, peasants would no longer have to submit themselves to gamonales. Velasco addressed this issue during his speech on the day that he enacted the Agrarian Reform. He stated:

From this joyful 24th of June onward, Peruvian peasants will be truly free citizens, whom the country finally acknowledges the right to the crops of the land they till, and a fair position in a society where they will no longer be second class citizens, people to be exploited by other people. (1970)

In the short passage above, we find several words that are often present in the dogmatism of human rights, namely citizen, right, justice, and society. The fact that these words are commonly used in the debate of human rights does not mean that Velasco was an activist or respectful of all human rights. However, there is definitely, at least, 
in theory an intention on his part to convey a message acknowledging the need to change the despicable status of peasants.

Velasco's discourse was a diagnosis of the basic problems that Peruvian peasants faced. Not owning, at least, a substantial part of the land in which they worked, made peasants socially and economically dependent. That dependence made them, in turn, vulnerable since their only possible livelihood was contingent upon the will of landowners. In that regard, Velasco stated:

It is essentially unfair, a system in which most of the land-and the best land-belongs to very few, as it happened until just yesterday in our country. This unbalanced and unfair situation comes to an end by means of the Agrarian Reform Law that the Revolutionary Government has just passed. Property is guaranteed, but within the limits that make it compatible with the inalienable social function that it ought to fulfill. (1970)

Latifundia and their social unfairness were explicitly identified as core issues in the rural world. Essentially, the hoarding of land which dated back to the sixteenth century had not changed. The Reform did not mean to expropriate land for the sake of revenge or resentment. It sought to restore the social function that land had once had in Perú. This social function consisted in allowing members of a community to have access to crops because of their joint work. Thomas Ankersen and Thomas Ruppert claim that "During the Inca period, [...] Ayllu" lands were divided into three parts, each having well-established boundaries: one part for the state, one part for supporting priests and religious ceremonies, and one part for the community" (Arkensen and Ruppert 2006). However, Velasco did not pretend to reinstitute the old communal system while abolishing private property. In his statement he makes it clear: "Land property is guaranteed, but within the limits that make it compatible with the inalienable social function that it

\footnotetext{
${ }^{5}$ Pablo F. Sendón defines the term Ayllu as a group of individuals related to one another by kinship.
} 
ought to fulfill" (1970). Therefore, the right to private land ownership was not abolished, but regulated. The people whose land was partly expropriated were to be compensated as Velasco said: "Those whose property is reduced by the enactment of this law will receive justified compensation from the State" (1970). It may be claimed that some people's rights were restricted to render justice to others. If so, it would be interesting to analyze how landowners had acquired the land that they claimed as theirs. To that purpose, let us refer to the essay "Mine, all mine" written by William Ryan. The author asserts that "[...] Europeans invented a new method of earning riches, that of 'discovery', and they came to America and claimed the land-on the grounds that they had never seen it before-and then went through the arduous labor of possessing by bounding [...]" (1982). The natives had been stripped of their land. Consequently, taking land away from those who had inherited it was by no means more unfair than the deprivation of land that the natives of Perú had experienced generation after generation. The questions that Ryan asks at the beginning of his essay are particularly relevant in this respect: "How do you get to own something? Well, you usually buy it. But how did the fellow you bought it from get to own it?" (1982). Tracing land ownership all the way back to its origin would have been the best way to appease the enraged gamonales in those days and their heirs and heiresses years later. Even so, Velasco acknowledged in his discourse the right that the relatively new owners held over their land and offered to compensate them. The offer is significant, considering the de facto nature of Velasco's government. Besides, there is no doubt that the acknowledgement of a person's property if legitimate is of utmost importance for the sake of individual and collective progress.

However, land ownership does not always have a rightful origin. In this regard, Ryan argues:

It is important to acknowledge a significant difference between achieving ownership simply by taking or claiming property and owning what we tend to call the 'fruit of labor.' If I, alone or together with family, work on the land and raise 
crops, or if I make something useful out of natural material, it seems reasonable and fair to claim that the crops or the objects belong to me or my family, are my property, at least, in the sense that I have first claim on them. (1982)

It is precisely the 'fruit of labor' that Velasco acknowledged as the main reason for peasants to be the rightful owners of land in Perú. On the contrary, gamonales had in most, if not all, cases become proprietors of vast plots of land by foul means. If the encomienda system simply changed name and became latifundia, it is reasonable to think that the origin of their tenure was illegitimate. Despite its illegitimacy, the encomienda system imposed on the natives outlived the Colony. Once Perú became a republic, the system of land tenure continued to antagonize with that in existence prior to the Conquest. Not only was it about a new concept- individual property-, but the power that the tenure rendered to landowners. Ryan describes the way the concept of 'private property', imported from Europe, accounts for the shock the natives of the Americas experienced: "The Europeans' peculiar ideas about individuals claiming exclusive ownership of specific portions of God's earth seemed strange, at first incomprehensible and then irksomely eccentric. The Indians eventually learned to their sorrow that it was no eccentricity, but rather a murderous mania" (1982). That irresistible custom took different forms ranging from the overt eviction of peasants from the land they tilled to the more subtle 'legal' claims of ownership on the part of the gamonales. The abuses were in all the cases targeted at the Indians.

Therefore, disregarding the racial component that was linked to the Agrarian Reform would be hypocritical. Velasco understood that extensive land property had allowed landowners to violate peasants' rights. On the one hand, owning land was associated with social, political, and economic power. Land dispossession, on the other, was synonymous with deprivation of even basic rights. To restore, at least, in part the dignity of the natives of Perú who tilled the land, Velasco targeted at the source of the problem. If the land that a 
minority owned and the abusive attributions that derived from this tenure were to blame for the deplorable condition of peasants, a reform was necessary. He claimed: "But conscientiously, you will have to admit that the Agrarian Reform is an unpostponable act of justice" (1970). Once again 'justice' is at the core of his discourse. He admitted that the Agrarian Reform was the only way to restore a sense of justice among the indigenous peoples of Perú:

That is why, in order to respond to the clamor for justice and the right of the most impoverished, the Law of the Agrarian Reform has backed up that big mass of peasants that make up the indigenous communities that, as of today-leaving behind an epithet customarily filled with racism and unacceptable prejudice-will be called Peasants' Communities. (Velasco 1970)

Velasco explicitly addressed racism as the underlying problem of the condition of Peruvian peasants. He vindicated the terms 'community' and 'peasant' so that together they could claim back a past free from humiliation. He also placed at the center of the need for the Agrarian Reform "the clamor for justice and the right of the most impoverished." Although the language used in his discourse may be labeled as 'populist', the truth is that peasants were socially, politically, and economically discriminated against.

The most impoverished were not only discriminated against but deprived of several core rights; among them were civil, political, and economic protections. Some of these human rights are interrelated. For example, the right of freedom from discrimination may pertain to social, political, and economic fields. As far as Perú is concerned, prior to the Agrarian Reform, latifundia had civil, political, and economic implications. Landowners often usurped the roles of the legislative, judicial, and executive authorities such as those stated in the standing Political Constitution of 1933 that dealt with the prerogatives of the Executive Power (Chapter I), the Legislative Power (Title V), and Individual Guarantees (Chapter II). To have an idea of the magnitude of the problem, let us consider the analysis that Mac-Lean makes of 
the distribution of land tenure in Perú in the mid-1960s. He states that "Extensive land tenure, in other words, latifundia both on the coast and in the highlands dominate, thanks to the actions of their legal representatives and their huge interests, the political, economic, and social life of the Nation. One per cent of big proprietors monopolize 62.8 per cent of arable land" (1965). Mac-Lean reveals staggering figures related to the existing monopoly of arable land. While this economic practice favored a white minority of creoles ${ }^{6}$, it excluded most peasants from their right to own land. Mac-Lean goes on to denounce the foul means by which landowners dispossessed peasants of land on the Peruvian coast: "[Latifundia] have expanded through arbitrariness, abuse, illegal appropriation and usurpation in not a few cases with the complicit consent of venal authorities or corrupt magistrates" (1965). The question posed by Ryan previously: "How did the fellow you bought it from get to own it?" can be answered by summarizing Mac-Lean's statement: most likely fraudulently. The deprivation of the right of peasants to own land constitutes a violation of an economic right. However, there were several other human rights violations committed against Peruvian peasants.

Another common violation to which peasants were subjected to was that of the right to just and favorable remuneration. In his analysis of the Chinchero case, Contreras gives several instances of ways in which peasants were either paid little money or no money at all. He states that gamonales, allied with local authorities, organized workweeks for peasants to till their lands for free. This practice violated the Peruvian Constitution of 1933, which was still standing when the Agrarian Reform was enacted. In its $42^{\text {nd }}$ article, the Constitution stated: "The State guarantees the freedom of labor [...]".

\footnotetext{
${ }^{6}$ According to Helen Busch and Mary T. Williams, the term creole was first used in the sixteenth century to identify descendants of French, Spanish, or Portuguese settlers living in the West Indies and Latin America.
} 
Another constitutional right that was overtly violated was the $55^{\text {th }}$ article, which stated "Nobody can be obliged to work without their free consent and without an adequate remuneration" (Political Constitution of Perú of 1933). Additionally, peasants were subjected to physical punishment. In a testimony from the documentary "La Reforma Agraria y el fin de la servidumbre en el Perú” [The Agrarian Reform and the end of servitude in Perú], Hilario Gallegos recalls: "We were beaten up for the slightest mistake. If two of us helped each other, the owner would punish us with a trashing" (Archivo Peruano..., 2014, 2:44-2:52). Although the $45^{\text {th }}$ article of the Constitution stated that the State promoted the defense of workers and employees, the right to personal security was absent from the territories of the gamonales. They could abuse peasants physically and they used to get away with it. Their supposed paternalistic figure usually resembled that of a merciless master. Gamonales, indeed, treated peasants as if they were inferior beings. The narrator of the documentary featuring Hilario Gallegos says that "As a child Hilario worked twelve hours a day, shelling maize until his hands bled. In return for the work that he did, he received a piece of bread" (Archivo Peruano..., 2014, 1:55-2:04). It is evident that the right to an adequate remuneration was also violated. Furthermore, Hilario's case depicts a clear transgression of the $52^{\text {nd }}$ constitutional article. This article acknowledges that the State has the fundamental duty of protecting the physical, mental, and moral health of children. Certainly, exploitation was one of the main characteristics of gamonalismo. Hilario goes on to talk about the misery that he and his family members faced while working in the 'owner's' land: "We worked hard, but we lived in misery. We had to clothe ourselves because the owner never gave us anything. He did not even send us to school, which is why none of us can read or write" (Archivo Peruano..., 2014, 2:32$2: 43$ ). By having to work twelve hours a day as a child, there was no way Hilario could have gone to school. The $72^{\text {nd }}$ article of the Constitution stated that "Elementary schooling is compulsory and free of charge.” Therefore, Hilario's right to education was violated. 
Sadly, this was the case of thousands of children living under the rule of landowners in Perú.

Overall, the living standard of peasants was of infamous quality. As an indicator of the precarious life that they led, Mac-Lean reveals that the low pay that peasants in Puno [southern highlands of Perú] received daily was one sol and sixty cents-a nickel-. According to Mac-Lean, "Scientific research conducted in those peasants proved that each person had a deficit of 1,500 calories per day" (1965). The little money that peasants made was not even enough for them to buy nutritious food, let alone to have access to proper health services, clothing, and recreational activities. As a matter of fact, inequality was rampant not only in terms of opportunities for education, living standard, and personal development, but also before the law. Basically, the right to equality before the law did not exist for peasants. The law was merely an instrument that landowners used to exert their power to its fullest capacity. If the law did not favor landowners, it simply did not exist. As Mac-Lean puts it: "There are landowners who are convinced that laws are not applicable to them" (1965). Under those circumstances, peasants lived in a permanent quasi state of exception since those authorities who were supposed to enforce the law and administer justice usually colluded with landowners. MacLean adds:

There are also farms-Chanchamayo is one of them-where abuses and predations against peasants are rampant because those latifundia are exempted from all types of administrative control, internal security, and local justice; without a police station; so peasants prefer to fix problems in a direct way because authorities (justice of the peace or deputy governor) are always landowners, or their employees turn out to be the ones who administer justice, adapting it to the interests and the whims of their masters. (1965)

As noted, latifundia were the source of excesses and violations on the part of landowners. Real life situations like those in Chanchamayo usually contradicted standing legislation. For instance, the $220^{\text {th }}$ 
article in the Constitution of 1933 stated that "the Power of Administering Justice is exercised by tribunals and courts provided with the guarantees and according to the proceedings established by the Constitution and the law." Owning large plots of land in Perú was synonymous with having unlimited social, economic, and political power. Such power was used to the detriment of peasants. They were often victims of crimes that ranged from monetary deprivation to physical abuse. Therefore, the Agrarian Reform was supposed to address the injustice of a neo-feudal system that latifundia had created beyond the dispossession of peasants.

\section{The Effects of the Reform on the Human Rights of Peasants}

Decades after the Agrarian Reform was enacted, its results still generate controversy. On the one hand, there are people who believe it was an economic failure. On the other hand, there are people who extol its social ramifications. Historian Antonio Zapata is among those who consider that the Agrarian Reform was a positive event. He emphasizes the social aspect of the Reform:

The Agrarian Reform left something immaterial that is valuable: a sense of citizenry. The person who belonged to the working class was a serf before [the Reform], and peasants took over the land and gained certain rights. [...]. Communities also gained certain benefits from farms. So, it generated a kind of social citizenry, and I believe that is a fact. From that moment on, Perú started to participate in modernity, leaving behind the days of gamonales, the days of servitude, and peasants became free individuals. And that is a key moment. Perú was no longer the same. Perú became a country where the ground of equality got bigger. We stopped living in the atrocious system of servitude [...]. Velasco freed peasants from bondage ties. (Zapata, 2016, 5:40-7:12) 
When Zapata talks about the valuable immateriality of the Reform, he questions those who merely focus their analysis on economic matters. For him, the citizenry of peasants represents a significant achievement of the Reform, and, in his opinion, this event alone changed the status of Perú as a country. Before the Reform, Perú was a pre-modern country if judged based on the condition of peasants. Certainly, the fact that peasants became citizens after the Reform means that their right to decide for themselves on private matters as well as to participate in local and national affairs was finally acknowledged. It also means that within the boundaries of the same country there used to be, at least, two types of individuals: citizens and non-citizens. This distinction was per sea source of inequality that the Reform addressed.

By acknowledging the right of peasants to equality before the law, the Reform brought about remarkable social and political changes. Sociologist Fernando Eguren asserts that despite the shortcomings of the Reform, it had a positive impact on the lives of peasants. He states that "[...] the social and political changes introduced by the Reform were substantial. The rural society was democratized, at least, in relative terms" (2008). Eguren claims that this radical change was possible because landowners, who had been all mighty in previous years, lost the source of their power and were unable to continue exerting unlimited influence in their former domains. As a result, more democratic conditions were accessible to peasants (2008).

It is obvious that democracy plays a key role when it comes to the recognition of a person's dignity. It allows members of a community to exercise their rights based on equality. The quality of a democracy can then be determined based upon the observance of the dignity of its members. With regards to the connection between human dignity and democracy Jûrgen Habermas states that:

Human dignity performs the function of a seismograph that registers what is constitutive for a democratic legal order, namely just those rights that the citizens of a political 
community must grant themselves if they are to be able to respect one another as members of a voluntary association of free and equal persons. (2010)

Nevertheless, it may be argued that Velasco's government was a de facto regime, thus there was no way it could have been democratic. Undoubtedly, his military administration was typical of a dictatorship in terms of civil liberties. However, the meaning of democracy, in this case, is not limited only to the form in which a government is elected and the way in which civil liberties are exercised. In this context, democracy is used to signify inclusion, the recognition of the equal value of all members of a country before the law. That is a basic benchmark of human dignity in a society, and Habermas acknowledges its importance. As mentioned before, prior to the Reform, Peruvian rural areas were on a par with feudal states. Landowners concentrated all kinds of power and used it to their own benefit at the expense of peasants. Nevertheless, the Reform affected the dynamics of the dichotomous relationship between landowners and peasants. While it debilitated the power of the former, it empowered the latter. This does not mean that the power that landowners had lost was equivalent to the power that peasants gained. In fact, the change in the dynamics resulted in what Antonio Zapata refers to as "[...] a country where the ground of equality got bigger" (Zapata, 2016, 6:38-6:41). It is precisely the bigger sense of equality aroused by the Reform which allowed for the social defense of important cultural elements. In that respect, Eguren adds: "In addition, there was a series of programs fostered by the government that highlighted the peasants' culture, among these programs was establishing Quechua as an official language, using this language in radio and TV programs, and [organizing] regional and national music, dance, and handicrafts contests (2008). The humiliating condition in which peasants had lived for decades included a cultural standardization that marginalized the language and arts of the natives of Perú. Making Quechua, the language of the Incas and their descendants, an official language gave the Reform a vehicle to boost 
the self-esteem of those who spoke it. Furthermore, the promotion of different Andean forms of art contributed to giving peasants a sense of belonging, a sense of dignity.

Although the Reform is often criticized because of its negative economic impact, it should be valued because it restored the dignity of peasants. The two most prevalent factors used to determine either the success or failure of the Agrarian Reform are related to social and economic aspects. For example, Raúl Chao, manager of the Asociación de Promoción Agraria (ASPA) [Association of Agrarian Promotion] considers these two factors when assessing the Reform 40 years after it was enacted. He claims that "There are both positive and negative sides linked to economic and social aspects". The economic failure in his opinion was due to the excessive power given to the members of the cooperatives. He believes that peasants lacked the necessary knowledge to run the agricultural business effectively because "in those days, fifty per cent of the peasants were illiterate, and thirty per cent barely made it to high school". He asserts that cooperatives were run in a non-technical fashion because there was a lot of politics involved in their management. In contrast, Chao admits that there was a positive social aspect to the Reform. He believes that "The human aspect was important. People, in some cases, attended the literacy programs run by the cooperatives. The cooperatives built 20 houses because the farms had left the peasants living in very precarious houses" (CEPES, 2009, 1:57-4:19). The chances that the Reform would achieve economic success were few, given the lack of a solid managerial approach. However, it is important to note that peasants had to make decisions regarding the use of cooperative lands overnight. On the contrary, in their recent past, they had been deprived of the right to make any economic decisions, including those related to their individual economy. Also, peasants, who had had no access to democracy in any way, abused a democratic mechanism by allowing all cooperative members, regardless of their lack of expertise, to participate in the decision-making process on their lands. 
It is apparent that the new system of land tenure on the part of peasants went beyond an economic claim. If in the years prior to the Reform, land tenure had been a source of all types of abuses, after the Reform, the land granted to peasants became a form of restoring some of their rights. Agrarian leader Antón Huáscar highlights the social impact that the Reform had on the lives of peasants. He acknowledges that spaces for discussing communal affairs were created after the Reform. He also states that the new generations had more chances of better living standards. Huáscar concludes that peasants regained their dignity through the Reform (CEPES, 2009, 0:22-1:47). The fact that the agrarian leader does not mention anything with regards to the economic impact of the Reform may mean that he admits that it was an economic failure. However, he fully supports its social implications. By underscoring the social aspect and downplaying the economic implications of the Reform, the agrarian leader positions himself in favor of the defense of human rights. Dignity is at the center of his speech.

Another positive appraisal of the Reform is the one made by Fernando Eguren in his capacity as president of the Centro Peruano de Estudios Sociales [Peruvian Center of Social Studies] (CEPES). He asserts that the Reform had both positive and negative aspects; however, on balance, the results were amply positive. Two of the aspects that he considers in his analysis of the Reform are social justice and the economic factor. On these points he states:

Prior to the Reform there was an intolerable situation in terms not only of land tenure, but also in terms of the concentration of power and the abuses that derived from it. The Agrarian Reform, with all its flaws, introduced an important element of social justice." [...]. Finally, the Reform was an important economic event. In this aspect, there are both good and bad things. As far as the modern farms that were expropriated are concerned, it is very likely that there was a regression in terms of productivity and technology. So, I believe that it is important to not be only a defender of the Reform and say that 
it was wonderful. But, overall, I think that it was positive and historically necessary. (CEPES, 2009, 5:19-7:27)

Unlike Huáscar, Eguren considers both the economic and social impact of the Reform in his analysis. The assessment of these two factors leads him to conclude, without hesitation, that the positive results of the Reform outnumber the negative ones. He even reckons that the changes that emerged from the Reform marked a turning point in the history of Perú. For this reason, it is expected that those whose wealth and power were affected by the structural change that the Reform achieved focus their assessment only on the economic factor. That critique is bound to generate adherence because from an economic perspective the Reform had serious flaws. Nonetheless, it should be noted that peasants did not benefit from agriculture prior to the Reform. The only ones who did were landowners. In fact, the richer landowners became the more power they gained. That power was often exerted without limits and against peasants. Consequently, the economic mishaps that peasants might have faced because of the Reform were not new to them. They had lived in utter misery before, and their post-Reform poverty was not synonymous with servitude as it had been before.

\section{The Reform: Present and Future}

Given the influence of global trends, especially of neoliberalism, it is necessary to analyze the Agrarian Reform considering the present national and international contexts. With regard to this, Sofía Monsalve, secretary general of FIAN International (International Food First Information and Action Network) argues that the agrarian reforms that took place in different parts of the world, including Latin America, did not fulfill the objective of eradicating poverty from rural areas. She believes that agrarian reforms are a matter of human rights because "hunger is mainly a rural phenomenon: 80 per cent of people who suffer hunger live in rural areas" (2001). In Perú, 40 per cent of the people in rural areas live in poverty and another 40 per cent live in 
vulnerable condition, according to Eduardo Zegarra, expert in agricultural economics. He claims that poverty in rural areas in Latin America has basically the same origin:

Agricultural sectors are scattered in these countries, with a high cost of transport, dependent on natural resources and exposed to dangers; thus, attracting little capital. In these countries, most of the investments are channeled to urban areas, and very few to the rural ones. This imbalance means that productivity and income in rural areas are significantly lower than those in cities. Twenty per cent of the population live in rural areas, but they provide only five to six per cent of the production. These levels of inequality are dangerous for political and social stability. This matter also has an ethical dimension: a person born in a rural area is three times as likely to be poor as one who is born in a city. (2019)

Zegarra agrees with Monsalve on the origin of rural poverty. If low investment rates feature the economic dynamics of rural areas, production rates are bound to be low as well. In that respect, Monsalve argues that "Typically, poverty and social marginalization originate when these people [those living in rural areas] are deprived of access to productive resources, especially land" (2001). However, as Zegarra points out, there is also a need to maximize the productivity of the resources invested in rural areas. This implies that access to land should be accompanied by mechanisms and resources that enable peasants to generate sustainable profits. The incorporation of peasants into a modern and efficient productive system requires an adequate provision of human and material resources.

Moreover, the adjustments that should have been made to correct the original deficiencies of the Reform never took place. Indeed, as Enrique Mayer points out, the Reform in terms of effective application came to an end in 1975, as soon as Velasco was ousted from the government. Even so, the ramifications of the Reform are visible today. Regarding this, Mayer claims that post-Reform Perú is very different from that of earlier years. He states: 
Whether there is a before and an after Velasco's government, we can tell from the people in Congress today, the mayors of towns, and the presidents of regional governments Igovernors]compared with those who were in public offices during Belaunde's administration [the administration prior to the Reform] (Mayer, 2019, 37:38-37:58)

Mayer suggests that the participation of indigenous people in politics is a clear indicator of the way in which the Reform permeated Peruvian life. Prior to the Reform, indigenous people in rural areas were under the rule of landowners, unable to exercise any right whatsoever. Today the children and grandchildren of those who were oppressed may either elect or be elected to public offices. Despite the dismantling of the Reform, its residual effects are still visible, especially in social aspects. However, those peasants who were favored by the Reform face new challenges today. Unlike the 1960s and 1970s, the challenges that peasants need to deal with nowadays have an external origin. Indeed, they are part of a global threat. Jérémie Gilbert views these challenges as follows:

Probably the right to land is inherently conflictful, since land is an important source of wealth, culture, and social life. The distribution and access to land are not politically neutral, and the right to land affects the economic and social basis globally. Besides, the different economic, social, and cultural facets of the right to land create tensions among different interests, especially between the need to protect owners and the right of those people without access to land. Finally, the right to land is an essential element of economic growth; therefore, it affects a wide range of interested parties, including powerful foreign investors. (2013)

Foreign capitals are willing and ready to replace the old landowners of Perú. In the context of widespread poverty in Peruvian rural areas, international agribusinesses have gradually gained control of large stretches of land by means of a sustained program of purchases. The lack of human and monetary resources has pushed 
peasants to sell their land, which in most cases was their only property and source of income. While large-scale agriculture has brought modernity to rural areas, the loss of property on the part of peasants has serious implications. One of these implications relates to their status. Since peasants sell their land, they stop being landowners to become employees. Ica, on the southern coast of Perú, is an example of this trend. Professor Jorge Poma reveals pertinent statistics based on research. He states that:

In the past years, it is evident that in our area of study, almost $8 \%$ of the arable land available in the valley has become property of agribusiness and export companies. Exemplars of this process are the cases of two old cooperatives: "Santa Margarita" and "Rosario del Yauca", consisting of two thousand and one thousand hectares, respectively. The lands that used to belong to small and medium-sized growers belong to enterprises now. (2018)

If the trend that Poma exemplifies continues, within a few years, Ica will have replaced an important number of small and mediumsized growers with a group of companies made up of national and international investors. As a result, one of the main features of the Agrarian Reform will have disappeared. Many of the peasants that became landowners will reverse to their pre-Reform condition of agricultural workers without land. The dynamics of profit under which corporations operate prevent them from partnering with small and medium-sized growers. As a matter of fact, their interests are often in conflict with those of the community growers live in. Therefore, the less influence peasants can exert over corporations, the better for the businesses. Consequently, corporations usually place peasants in the periphery. In this way, cultural and social rights associated with land tenure become vulnerable. This is an increasing global trend, which affects Peruvian agriculture. Regarding this matter, Jérémie Gilbert believes that a human rights perspective is key to deal with the threat: 
[...] A human rights approach may be an important tool to guarantee that the economic value as well as the cultural value of land be acknowledged and that the rights of peoples over their lands be respected as a fundamental right. Indigenous peoples have been successful in the claim of their fundamental rights over land, and they have managed to include the rights to land in the vocabulary of human rights [...]. (2013)

Gilbert is aware that the huge influence that agribusinesses pose can only be countered by an equally powerful body. That is why, human rights emerge as a possible mechanism to defend people's rights to land and the corresponding derivative rights. Due to the key role that agriculture plays in Peruvian economic, social, and cultural life, Gilbert's call for a global response framed within human rights is worth considering.

However, agribusinesses are not the only threat that peasants face today. Other economically powerful businesses have set their eyes and laid their hands on rural lands with serious implications for peasants. Sofía Monsalve views this threat as follows:

For rural people the risk of dispossession and displacement from the lands and natural resources upon which they depend for their subsistence and livelihood is growing; international investments flowing into the energy sector, infrastructure, agribusiness, nature conservation and carbon sequestration projects, urbanization and industrialization are seeking to control ever bigger shares of land, water, fisheries, and forests. Global data show that increasing land concentration is a source of great concern. (2015)

While Monsalve points out the different threats that loom over peasants all around the world, she also reminds us that depriving peasants of their land implies affecting individual as well as communal lifestyles. By losing their relative economic independence first, peasants then must adhere to new social and cultural patterns to fit in a system that gradually takes over all the dimensions of human 
existence. As this is a global trend, Peruvian peasants face the same challenges.

\section{Conclusions}

Although there may be controversy regarding the economic success of the Reform, the impact that it has had on the implementation of basic human rights is meaningful. Indeed, the Reform, on a national level is, according to historian and sociologist Hugo Neira, “The most important event after Peru's independence" (Neira, 2019, 14:22-14:27). After the Reform, peasants were granted a fundamental human right to be used effectively: the right to freedom from slavery. Based on this prime right, peasants were entitled to claim other rights such as the right to property, the right to freedom from discrimination, the right to equality before the law, and the right to education, among others. The active participation of indigenous people in the political life of Perú at present is one of the positive outcomes of the Reform. However, more than fifty years after its enactment, the residual effects of the Reform are threatened by global economic trends, especially neoliberalism. Therefore, along with the assessment of the pros and cons of the Reform, progressive sectors should reach an agreement to protect the positive aspects that the Reform brought about. To that end, it is crucial that discussions take place considering a human rights perspective.

\section{Referencias}

Amado Gonzales, Donato. Reparto de tierras indígenas y la primera visita y composición general 1591-1595.

https://revistas.pucp.edu.pe/index.php/historica/article/view/ 8526 Accessed 26 December 2021.

Archivo Peruano de Imagen y Sonido. 2014, June 4. La Reforma Agraria y el fin de la servidumbre en el Perú. [The Agrarian Reform and the end of servitude in Perú] Documentary. You 
Tube https://www.youtube.com/watch?v=ONnphcPOhxI Accessed 19 September 2020.

Arkensen, Thomas and Thomas Ruppert. Tierra y Libertad. The Social Function Doctrine and Land Reform in Latin America, 19 (1):69-120. https://journals.tulane.edu/elj/article/view/2154 Accessed 24 December 2021

CBS. 2017, October 27. Cómo era el Perú antes de la Reforma Agraria. [What Perú was like before the Agrarian Reform] News report. You Tube. https://www.youtube.com/watch?v=sIGsJTa3luo Accessed 3 September 2019

CEPES. 2009, June 1. Reforma Agraria Perú: 40 años después. [The Agrarian Reform in Perú: 40 years later] Round table. You Tube. https://www.youtube.com/watch?v=RHfZUV_7_kI Accessed 28 September 2020.

Constitución Política del Perú de 1933.

https://www4.congreso.gob.pe/historico/quipu/constitu/1933. Accessed 23 December 2021.

Contreras, Jesús. 1981. El gamonalismo local y la reforma agraria: el caso de Chinchero. [Local gamonalismo and the Agrarian Reform: Chinchero's case] Boletín Americanista, 0(31):15-39. https://www.researchgate.net/publication/28264334_El_gamon alismo_local_y_la_reforma_agraria_el_caso_de_Chinchero_Per u_1940-1979 Accessed 11 October 2020.

Eguren, Fernando. 2008. La reforma agraria en el Perú. [The Agrarian Reform in Perú] Debate Agrario:análisis y alternativas. Gale OneFile: Informe Académico, https://link-galecom.lp.hscl.ufl.edu/apps/doc/A308005216/IFME?u=gain40375 \&sid=IFME\&xid=0f2c575c. Accessed 2 October 2020.

Gibson, Charles. 1966. Encomienda. In: Spain in America, 1st ed. Harper \& Row, New York.

Gilbert, Jérémie. 2013. Derecho a la tierra como derecho humano: Argumentos a favor de un derecho específico a la tierra. [The right to land as a human right: arguments in favor of a specific right to land] 18 Sur 123-145. https://sur.conectas.org/wpcontent/uploads/2017/11/sur18-esp-jeremie-gilbert.pdf Accessed 17 September 2020 
González Prada, Manuel. Horas de lucha. Revuelta Editores, 2021. Habermas, Jûrgen. 2010. The Concept of Human Dignity and the Realistic Utopia of Human Rights. Metaphilosophy (41) 4:464480.

Mac-Lean y Estenós, Roberto. 1965. La Reforma Agraria en el Perú. [The Agrarian Reform in Perú] Revista Mexicana de Sociología 27(1): 15-71.

Mariátegui, José Carlos. 2012. Siete ensayos de interpretación de la realidad peruana. [Seven Essays of Interpretation of the Peruvian Reality] Digitalia Inc., New York.

Mayer, Enrique. 2016, July11. Velasco y su reforma agraria. [Velasco and his Agrarian Reform] Conference. You Tube https://www.youtube.com/watch?v=hRM9sO3ZktYAccessed 13 0ctober 2020.

Monsalve, Sofía. 2001. Acceso a la tierra: una obligación de derechos humanos. [Access to land: a human rights obligation] 1-9 https://www.google.com/search?q=Monsalve+Su\%C3\%Alrez\% 2C+Sof\%C3\%ADa.+\%E2\%80\%9CAcceso+a+la+tierra\%3A+una+o bligaci\%C3\%B3n+de+derechos+humanos Accessed 28 0ctober 2020.

--- . 2015. The right to land and other natural resources. ResearchGate 1-9

https://www.researchgate.net/publication/308631743 The_rig ht to_land_and_other_natural_resources Accessed 18 June 2020.

Neira, Hugo .2019, June 27. A los 50 años de la Reforma Agraria en el Perú. [50 years after the Agrarian Reform in Perú] Conference. You Tube https://www.youtube.com/watch?v=3-7uqCDSZxY Accessed 5 September 2020.

Poma, Jorge. 2018. La concentración de la tierra: estudio de caso del valle de Ica. [Land concentration: a case study of Ica Valley] Apuntes de ciencia y sociedad 8 (1): 1-10.

http://journals.continental.edu.pe/index.php/apuntes/article/view/ 564 Accessed 26 November 2020.

Ryan, William .1982. Mine, all mine. In: Equality, 1st ed. Pantheon Books, New York, pp. 85-91, 1982. 
Sendón, Pablo F. Los ayllus de la porción oriental del departamento del Cusco. Aproximación comparativa desde el Collasuyu. Instituto Francés de Estudios Andinos, 2009. https://centroderecursos.cultura.pe/es/registrobibliografico/lo s-ayllus-de-la-porci\%C3\%B3n-oriental-del-departamento-delcusco-aproximaci\%C3\%B3n Accessed 23 December 2021.

Velasco, Juan .1970. Velasco, La voz de la Revolución: Discursos del presidente de la República, General de División Juan Velasco Alvarado. [The Voice of the Revolution: Speeches of the President, Division General Juan Velasco Alvarado]. Ediciones Peisa, Lima.

Zapata, Antonio. 2016, October 6. ¿Velasco jodió al Perú? [Did Velasco screw Perú?] Otra mirada. Interview. You Tube https://www.youtube.com/watch? $\mathrm{v}=10$ hjb234E58 Accessed 16 0ctober 2020.

Zegarra, Eduardo. 2019. La pobreza se agrava en Perú y América Latina. [Poverty is getting worse in Perú and Latin America] Grade. Interview. https://www.grade.org.pe/novedades/lapobreza-rural-se-agrava-en-peru-y-america-latina/ 